\title{
EFFECTS OF A PILATES SCHOOL PROGRAM ON HAMSTRINGS FLEXIBILITY OF ADOLESCENTS
}

\author{
EFEITOS DE UM PROGRAMA ESCOLAR DE PILATES SOBRE A FLEXIBILIDADE DOS ISQUIOTIBIAIS \\ DE ADOLESCENTES
}

Original Article

ARTIGO ORIGINAL

Artículo Original

\section{EFECTOS DE UN PROGRAMA ESCOLAR DE PILATES SOBRE LA FLEXIBILIDAD DE LOS ISQUIOSURALES DE ADOLESCENTES}

\author{
Noelia González-Gálvez' \\ (Physical educator) \\ María Carrasco Poyatos ${ }^{2}$ \\ (Physical educator) \\ Pablo Jorge Marcos Pardo² \\ (Physical educator) \\ Rodrigo Gomes de Souza Vale ${ }^{3}$ \\ (Physical educator) \\ Yuri Feito ${ }^{4}$ (Exercise physiologist) \\ 1. San Jorge University, Health \\ Sciences Department, \\ Zaragoza, Spain. \\ 2. Saint Anthony Catholic \\ University (UCAM), Physical \\ Activity and Sport Department, \\ Murcia, Spain. \\ 3. Universidade Estácio de Sá, \\ Laboratório de Fisiologia do \\ Exercício, Rio de Janeiro, Brasil. \\ 4. Kennesaw State University, \\ Department of Exercise Science and \\ Sport Management, Georgia, \\ United States.
}

\section{Correspondência:}

Carril de la condesa 31 1이 30010.

Murcia, Spain.ngonzalez@usj.es

\begin{abstract}
Introduction: Low levels of hamstring flexibility may trigger certain acute and chronic pathologies and injuries. Poor flexibility is observed among teenagers and several authors have recommended the use of specific programs in this population to improve flexibility levels. The Pilates Method (PM) may be an appropriate intervention to achieve this purpose and has rarely been used with this population. Objective: Study was to assess changes in the flexibility of hamstrings after running a didactic PM unit for high-school students. Methods. This research was developed through a quasi-experimental design. The sample consisted of 66 high-school students divided into experimental group ( $E G=39)$ and control group ( $C G=27)$. The intervention was carried out 2 times a week for six weeks. Each session lasted 55 minutes divided into three parts: warm-up, main part and cool down. Hamstring flexibility was assessed using the toe-touch test. Paired Student $t$-test and $t$-test for independent samples were applied. The size of the effect (d) was determined. Results: The EG showed significant provident in hamstring flexibility $(+3.54 \pm 3.9 \mathrm{~cm})$. The effect size was low ( $d>d>0,2<0,53)$, which means that a small proportion of participants improved their results. The control group did not have significant changes after the intervention. In the experimental group, both boys $(+3.38 \pm 3.7 \mathrm{~cm})$ and girls $(+3.85 \pm 4.2 \mathrm{~cm})$ showed significant improvements. The effect size was low for boys ( $d>d>0.2<0.53$ ), which means that a small proportion of participants improved their results, and high for girls ( $d>1.15$ ) which means that a large proportion of participants improved their results. Conclusion: This study showed that six-weeks of Pilates training in Physical Education classes has significantly improved the hamstrings flexibility among adolescents.
\end{abstract}

Keywords: adolescent, range of motion, articular, physical education and training.

\section{RESUMO}

Introdução: Baixos níveis de flexibilidade dos músculos isquiotibiais podem desencadear patologias elesões agudase crônicas. Esses níveis baixos são observados entre adolescentes, e diversos autores têm recomendado o uso de programas especificos nesta população para melhorar a flexibilidade. O método Pilates (MP) pode ser uma intervenção adequada para alcançar essa finalidade, mas raramente tem sido utilizado nessa população. Objetivo: Avaliar as alterações nos níveis de flexibilidade dos isquiotibiais após a aplicação de uma unidade didática do MP nas aulas de Educação Física para adolescentes. Métodos: Esta pesquisa foi desenvolvida por meio de um desenho quase-experimental. A amostra foi composta de 66 alunos do ensino médio, divididos em um grupo experimental (GE = 39) e um grupo controle $(G C=27)$. A intervenção foi realizada com frequência de duas vezes por semana durante seis semanas. Cada sessão durou 55 minutos e foi dividida em três partes: aquecimento, parte principal e relaxamento. Os níveis de flexibilidade dos isquiotibiais foram avaliados através do teste de toque nos dedos dos pés. Foram empregados testes $t$ de Student pareado e, para amostras independentes o teste t. O tamanho do efeito (d) foi calculado. Resultados: O GE apresentou aumento significativo dos níveis de flexibilidade dos isquiotibiais $(+3,54 \pm 3,9 \mathrm{~cm})$. O tamanho do efeito foi bai$x o(d>d>0,2<0,53)$, o que significa que uma pequena parte dos participantes melhorou seu resultado. O GC não apresentou alterações significativas após o período de treinamento. No $G E$, os grupos masculino $(+3,38 \pm 3,7 \mathrm{~cm})$ e feminino $(+3,85 \pm 4,2 \mathrm{~cm})$ apresentaram melhoras significativas. Otamanho do efeito foi baixo para o grupo masculino ( $d>d>0,2<0,53)$, o que significa que uma pequena parte dos participantes melhorou seu resultado, e foi alto para o grupo feminino $(d>1,15)$, mostrando que grande parte dos adolescentes melhorou seu resultado. Conclusão: Este estudo mostrou que seis semanas de aplicação do método de Pilates nas aulas de Educação Física proporcionaram melhoras significativas nos niveis de flexibilidade dos isquiotibiais entre os adolescentes.

Palavras-chave: adolescente, amplitude de movimento articular, educação física e treinamento.

\section{RESUMEN}

Introducción: Bajos niveles de flexibilidad de la musculatura isquiosural pueden desencadenar ciertas patologías y lesiones agudas y crónicas. Se observa una pobre flexibilidad entre los adolescentes y varios autores han recomendado el uso de programas específicos en esta población para mejorar los niveles de flexibilidad. El Método Pilates 
(MP) puede ser una intervención adecuada para lograr este propósito, y rara vez se ha utilizado con esta población. Objetivo: Evaluar los cambios en la flexibilidad de los isquiosurales después de enseñar una unidad didáctica con el MP en jóvenes adolescentes. Métodos: Esta investigación se desarrolla a través de un diseño cuasi-experimental. La muestra estuvo formada por 66 estudiantes de secundaria divididos en grupo experimental (GE = 39) y grupo control (GC = 27). La intervención se llevó a cabo 2 veces a la semana durante seis semanas. Cada sesión duró 55 minutos divididos en tres partes: calentamiento, parte principal y relajación. La flexibilidad de los isquiosurales se evaluó mediante la prueba toe-touch. Se aplicaron pruebas pareadas $t$ de Student y pruebas t para muestras independientes. Se determinó el tamaño del efecto (d). Resultados: El GE mostró significativamente una mejora en la flexibilidad isquiosural ( $+3,54 \pm 3,9 \mathrm{~cm})$. El tamaño del efecto fue bajo ( $d\rangle d\rangle 0,2<0,53)$, lo que significa que una pequeña proporción de los participantes mejoraron sus resultados. El GC no tuvo cambios significativos después de la intervención. En el $G E$, tanto los niños $(+3,38 \pm 3,7 \mathrm{~cm})$ como las niñas $(3,85 \pm 4,2 \mathrm{~cm})$ mostraron mejoras significativas. El tamaño del efecto fue bajo para los varones ( $d>d>0,2<0,53$ ), lo que significa que una pequeña proporción de los participantes mejoraron sus resultados, y alto para las niñas $(d>1,15)$ lo que significa que una gran proporción de los participantes mejoraron sus resultados. Conclusión: Este estudio mostró que seis semanas de instrucción de Pilates en las clases de Educación Física mejoran de manera significativa la flexibilidad de los isquiosurales entre los adolescentes.

Palabras clave: adolescente, rango del movimiento articular, educación y entrenamiento físico.

\section{INTRODUCTION}

Lack of flexibility and muscular stiffness has been linked with increased risk of musculoskeletal injury ${ }^{1,2}$. Specifically, the muscles of the posterior leg, commonly known as the hamstring, have a greater tendency to shorten without proper conditioning. Lack of flexibility in the hamstring muscles is directly related with low back pain in adults and adolescents ${ }^{3}$.

Shortening the hamstring causes increased pelvic tilt and increased lumbar and/or dorsal kyphosis, especially during trunk flexion. Thus, it is associated with conditions such as back pain, kyphosis, lumbar spine investments, spondylolisthesis and herniated discs. In addition, tight hamstrings may lead to acute injuries (sprains or strains) and chronic conditions, most notably groin injuries ${ }^{4,5}$.

There is evidence that supports the use of exercise as a therapeutic tool to improve flexibility ${ }^{3}$. Considering the high rates of back pain among adolescents (10-59\%) (6,7 $^{6}$ and the poor flexibility values observed among school aged children ${ }^{5,8}$ this has influenced the offering of flexibility programs during school hours among school aged children.

A systematic training program has shown to increase flexibility among adults, by achieving a steady increase in the length of the muscle-tendon unit, and consequently a greater range of joint movement ${ }^{9}$. In addition, similar improvements have been shown in adolescents with flexibility raining ${ }^{10-18}$.

The Pilates Method (PM) is a body conditioning technique, which offers improved control through stretching and strengthening of muscles while improving flexibility, reducing pain and preventing injuries. The PM is based on the premise that the body's musculature needs stretching ${ }^{17,18}$. This method seeks to maintain the natural curves of the spine, while maintaining a neutral pelvis and maintaining the cervical and lumbar curves ${ }^{19}$. Several studies have shown significant improvements in hamstring flexibility and vertebral column following the application of a PM program among adults ${ }^{20-22}$. Even though the PM method may provide flexibility improvements in adolescents, this has not been shown effectively. Thus, this generates several hypothesis of a six-weeks PM based exercise program with GE teenagers, which include: 1) a significantly improvement in the flexibility of the hamstring muscles; 2) significant differences in flexibility between an experimental and control group, and between boys and girls; and 3) the MP is more effective in improving hamstring flexibility than other specific programs flexibility.

Therefore, the primary aims of this study were to assess the effect of a Pilates Method based training program on the hamstring flexibility of school-aged children, between boys and girls, and to compare the efficacy of the PM to improve flexibility.

\section{METHODS}

This research was developed through a quasi-experimental design with a control group (CG) and experimental group (EG), including pre and post-tests, with analysis between groups, within groups and between gender.

Participants were selected from a secondary school in Murcia, Spain, through a purposive sampling. Inclusion criteria for each student included parental consent and assertion each student was free of musculoskeletal, neurological, cardiac, metabolic or rheumatic conditions to actively participating in physical education sessions and regular evaluations; and to not miss more than one session of the program (attendance of 91.66\%).

Students with prior history of spine pathologies/injuries or who had received previous treatment for back injuries were excluded from the study, although they were part of their regular class groups during training. All parents and/or guardians signed a consent form approved by the "Scientific and Ethical Committee" of the San Antonio Catholic University of Murcia, Spain.

The sample consisted of 66 students ( 41 boys and 25 girls), belonging to the third year of secondary education. They were randomized into two groups: experimental group ( $E G, n=39)$ and control group (CG, $n=27)$. The basic characteristics of the samples are presented in table 1.

Table 1. Sample characteristics (Mean \pm SD).

\begin{tabular}{|c|c|c|c|}
\hline & & $C G(n=27)$ & EG $(n=39)$ \\
\hline \multicolumn{2}{|c|}{ Age (years) } & $14 \pm 0.5$ & $14.4 \pm 0.6$ \\
\hline \multirow{2}{*}{ Gender } & Male & 15 & 26 \\
\hline & Female & 12 & 13 \\
\hline \multicolumn{2}{|c|}{ Weight (kg) } & $67.2 \pm 14.5$ & $64.0 \pm 11.6$ \\
\hline \multicolumn{2}{|c|}{ Height $(\mathrm{cm})$} & $167.8 \pm 7.7$ & $167.4 \pm 8.3$ \\
\hline \multicolumn{2}{|c|}{ BMI $\left(\mathrm{kg} / \mathrm{m}^{2}\right)$} & $23.8 \pm 4.5$ & $22.8 \pm 3.5$ \\
\hline
\end{tabular}




\section{MATERIALS}

Height $(\mathrm{cm})$ and weight $(\mathrm{kg})$ were measured without shoes using digital medical scale SECA220k (Barcelona, Spain). Body mass index was calculated as $\mathrm{kg} / \mathrm{m}^{2}$.

Toe-touch test was chosen because of its simple administration, because it requires very little instruction and little training and can be used to test large number of students in a short period of time9, ${ }^{9,23}$. Its validity and reliability has been demonstrated in several other studies 24,25. All tests were performed by the same investigator, whose test in reliability was tested prior to the study with a double-blind study of 30 participants, obtaining a correlation coefficient higher than 95\%. All tests were performed twice with an interval of two weeks.

To perform the test, the student stood on the box with knees and feet shoulder width apart. They performed a maximal trunk flexion without bending the knees and with arms and palms outstretched over the ruler of the box (figure 1). The zero-point was in line with the edge of the box where the participants were standing. Values above the standing box were considered negative, while those below were considered positive. All measurements were recorded in centimeters $(\mathrm{cm})$. We consider normal values those greater than or equal to $-5 \mathrm{~cm}$. Values between -5 and $-12 \mathrm{~cm}$ were considered as hamstring shortness type I, and values greater than $-12 \mathrm{~cm}$ where considered hamstring shortening type $\|{ }^{26}$.

\section{Exercise program}

The study was carried during six-weeks, coinciding with the development of a teaching unit. Each unit was delivered by the physical education instructor twice a week for 55 minutes each. Investigators developed the teaching unit based on the PM and the control group

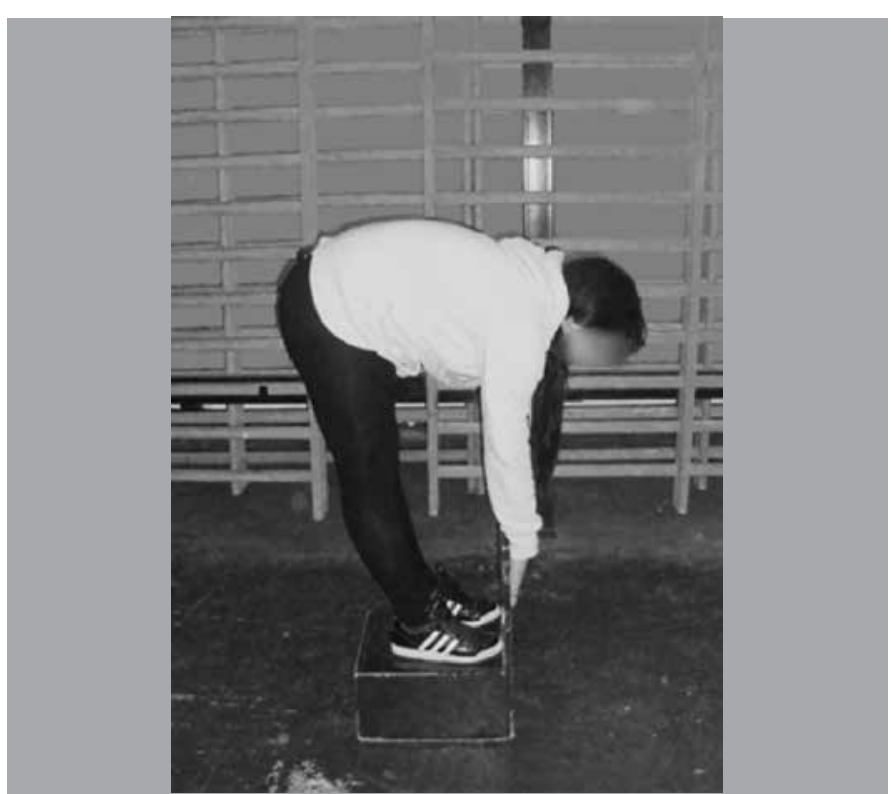

Figure 1. Toe-touch test. based on their regular Physical Education sessions. All students attended at least $92 \%$ of all classes ${ }^{27}$.

Each session began with basic components and gradually incorporating principles and exercises of increasing complexity. The sessions were divided into warm-up, main movements phase and cool-down. The instructor conducting the didactic units was the physical education professor of all participating groups. Prior to the start of each didactic unit the investigators met with the instructor several times to examine each exercise used in the sessions and ensure correct implementation.

\section{Teaching Development Unit}

The main movement phase had a total duration of 41 minutes, accounting for $74.5 \%$ of the session. This section was carried using the bulk of PM exercises. During the first six sessions explanation of the breathing technique, integrating of the PM principles and a repertoire of basic exercises were included. The next four sessions included basic-to-intermediate exercises and incorporated the concept of correct segmental placement. The last two sessions served to consolidate the knowledge acquired and practiced the variety of exercises learned. The cool-down lasted seven minutes, focused on stretching and flexibility exercises. Several PM exercise were selected for the cool-down: the hundred, half roll-up, one leg circle, rolling back, one leg stretch, swan-dive, one leg kick, neck pull, scissors, bicycle, shoulder bridge, side kicks, swimming, side bend, and the seal. As an example, we have included the warm up (figure 2) and cool-down (figure 3) routines. In addition, we have included the progression we followed for the proper increase in intensity of two specific exercises (figures 4 and 5).

\section{Statistical analysis}

We carried out a descriptive analysis (mean, standard deviation and range). To determine possible changes in the same variable, we used the T-test for related samples. To examine differences in the same variable between groups, we used the T-test for independent samples. The size of the effect (d) was determined either for the differences between groups or for the changes in each group. Statistical analysis was performed with SPSS 15.0 for Windows. The significance level was set at $p<0.05$.

\section{RESULTS}

Figure 6 shows the grades of shortness of the hamstring muscles between the control and experimental groups. Grouping variables are presented based on studies from Santonja et al. ${ }^{26}$. In addition, we show the changes occurred in each group after the Pilates intervention.

Figure 7 shows the values for the pre- and post-test of the toe-touch test for the control and experimental groups. The EG showed a significant improvement of $3.54 \pm 3.9 \mathrm{~cm}$.

The effect size was low ( $d>d>0,2<0,53)$, which means that a small proportion of participants improved their results. The control group did not have significant changes after the intervention. No significant

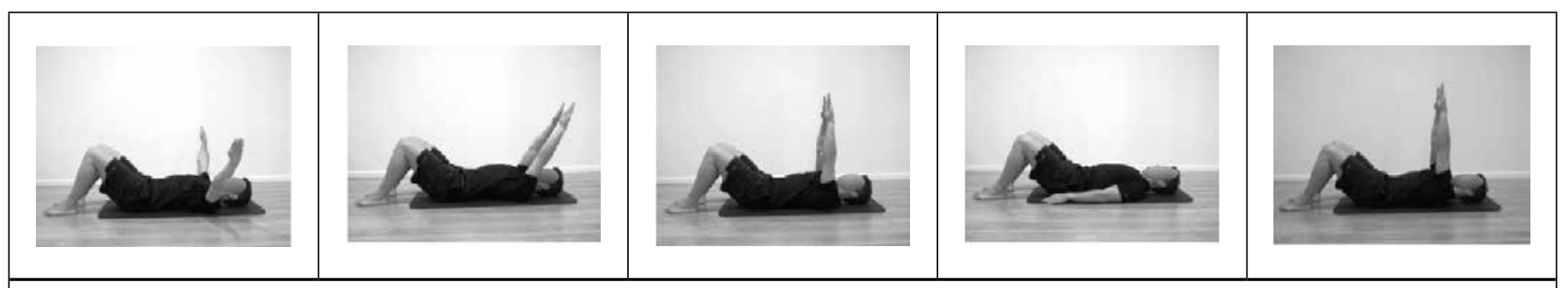

Breathing, scapular-humeral movements, cervical, thoracic, lumbar, pelvis, coxal-femoral, knees and ankles.

Figure 2. Example of warming supine. 


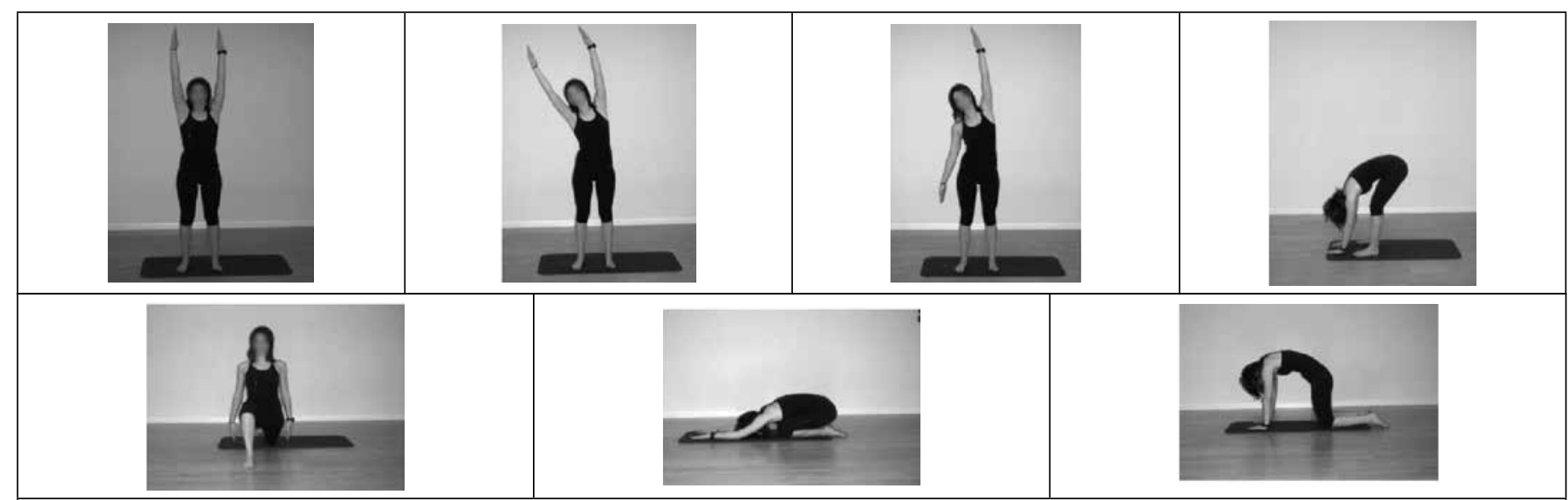

Standing Stretches: Stretching back-abdominal, bilateral, unilateral, hamstring and paraspinal with legs together and apart, iliopsoas, drink or position of rest and cat-camell. The movements are performed coordinated with the breath, there is no static moment. Each exercise is repeated 8 times.

Figure 3. Example of cool down standing.

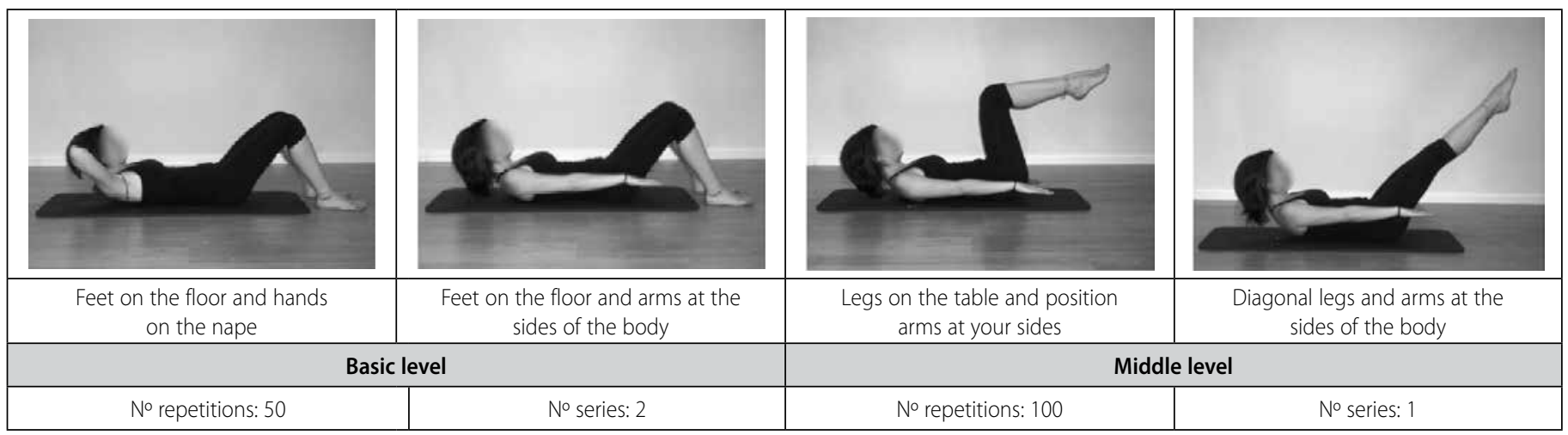

Figure 4. Progressions of "the hundred".

\begin{tabular}{|c|c|c|c|}
\hline \begin{tabular}{|l|l|} 
Buttocks and lower back off \\
and land back
\end{tabular} & $\begin{array}{c}\text { In position 1 to extend a knee } \\
\text { (alternatively) }\end{array}$ & $\begin{array}{c}\text { In position } 1 \text { position placing one } \\
\text { leg on the table placed }\end{array}$ & Middle level \\
\hline No repetitions: 8 & No repetitions: 12 & No series: 2 \\
\hline
\end{tabular}

Figure 5. Progressions of "shoulder bridge".

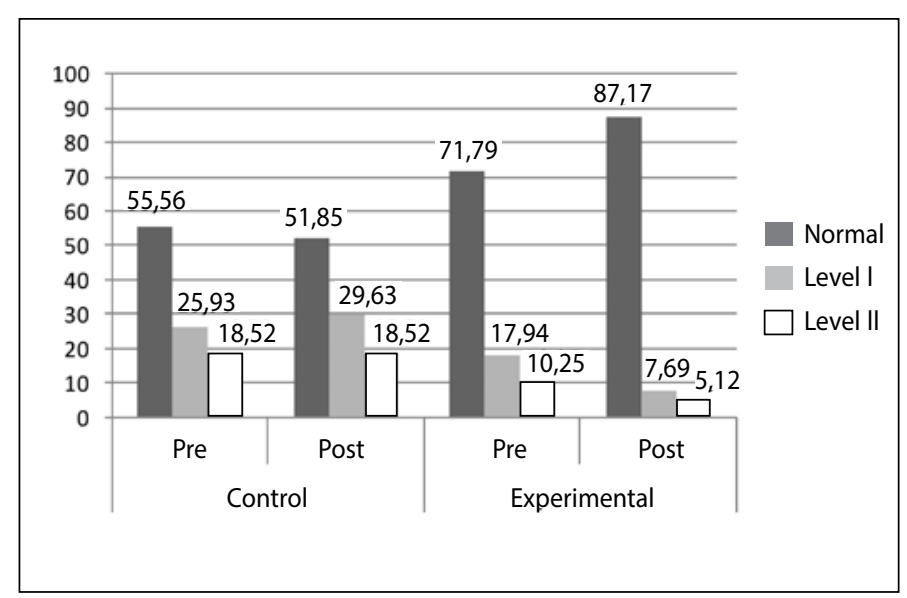

Figure 6. Percent distribution of cases in CG and EG in the pre- and post-test. differences were seen between the two groups in the pre-test. However, these differences were significant at the post-test. Table 2 shows the results based on gender for the control and experimental groups. In the experimental group, both boys $(+3.38 \pm 3.7 \mathrm{~cm})$ and girls $(+3.85$ $\pm 4.2 \mathrm{~cm}$ ) showed significant improvements (figure 8 ). The effect size was low for boys ( $d>d>0,2<0,53$ ), which means that a small proportion of participants improved their results, and high for girls $(d>1,15)$ which means that a large proportion of participants improved their results. No significant changes were observed for boys or girls in the CG.

\section{DISCUSSION}

After six-weeks of exercise using the Pilates method, boys and girls showed significant improvements in hamstring flexibility compared to those who only participated in a typical physical education course.

The influence of specific flexibility program have been evalua- 


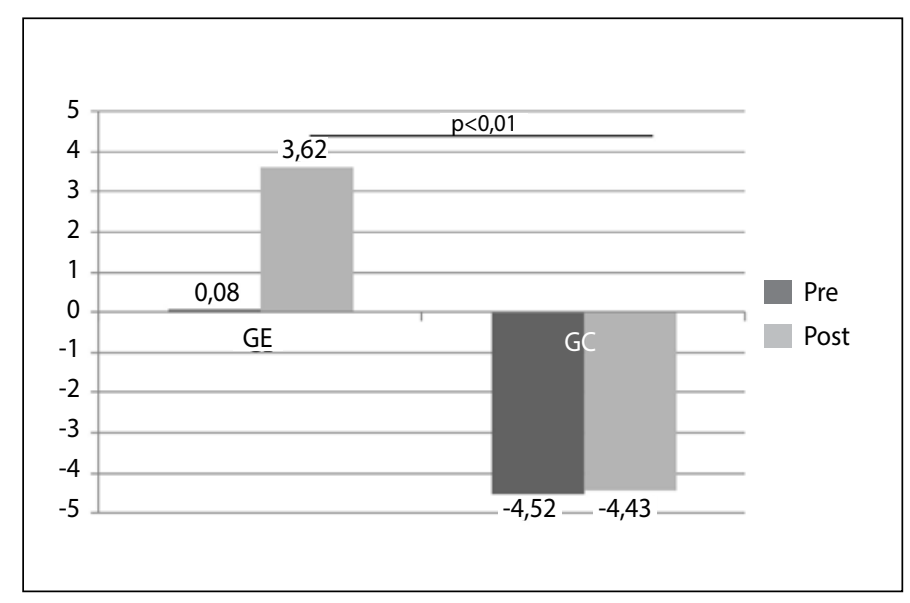

Figure 7. Differences between groups in the pre- and post-test.

Table 2. Sex differences in the toe-touch test (Mean \pm SD).

\begin{tabular}{c|c|c|c|c}
\hline & \multicolumn{2}{|c|}{ EG } & \multicolumn{2}{c}{ CG } \\
\hline & Boys & Girls & Boys & Girls \\
\hline Pre & $-2.19 \pm 8.5$ & $4.62 \pm 9.9$ & $-8.93 \pm 5.75$ & $1.00 \pm 5.66$ \\
\hline Post & $1.19 \pm 8.14^{*}$ & $8.47 \pm 8.4^{*}$ & $-8.87 \pm 5.86$ & $1.13 \pm 7.29$ \\
\hline
\end{tabular}

*Significant differences compared to pre-test $(p<0.01)$.

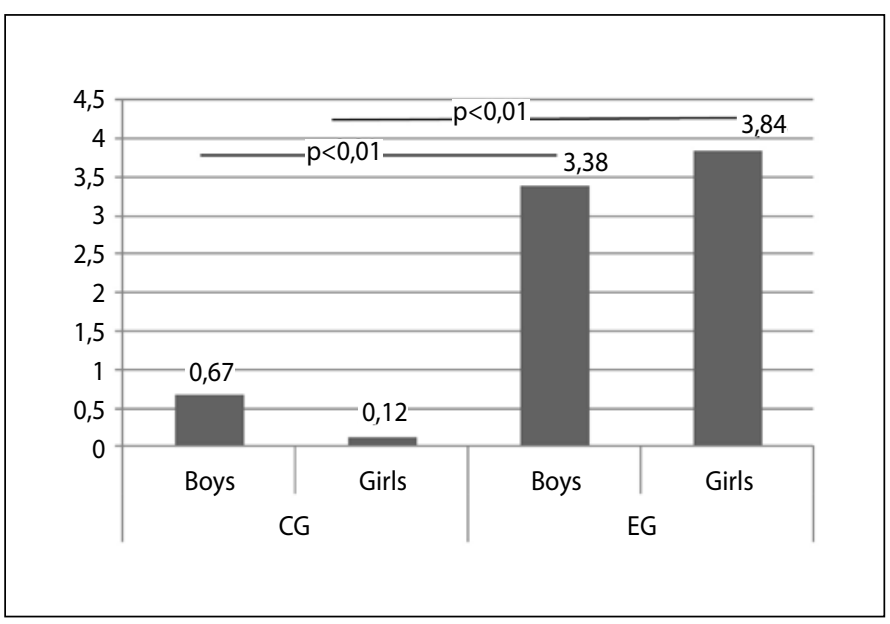

Figure 8. Gender differences between groups for pre- and post-test.

ted in different studies. Similar to our findings, intervention programs ranging from 5 to 32 weeks, performed 2 to 4 times per week, all have shown significant improvements in hamstring flexibility ${ }^{10-18}$.

However, it must be noted that some studies utilize angular tests: 90/90 test ${ }^{10,11}$ and Straight Leg Raise test (SLR) ${ }^{12,13}$ while others, similar to ours, utilize linear tests: Sit and Reach Test (SRT) $)^{12,14-18}$ and Toe-touch test $(T T)^{12}$. Thus, it is not possible to compare our study with those using angular tests, and we should use caution when comparing studies that use the SRT and those using the TT. Sainz de Baranda et al. ${ }^{12}$ implemented several intervention programs to improve flexibility and obtained improvements in all experimental groups (EG1 (32 week; 2 session/weeks), EG2 (64 week; 2 session/weeks) and EG3 (32 week; 4 session/weeks); 5,7 and $14 \mathrm{~cm}$, respectively.

Valdivia et al. ${ }^{13}$ in 12-13 years old children, obtained an improvement of $1.86 \mathrm{~cm}$ after application of a specific program to improve flexibility (2 sessions/week, 32 weeks). Coledam et al. ${ }^{14}$ carried out a flexibility specific program (2 sessions/week; 16 weeks) and obtained an improvement of $4.53 \mathrm{~cm}$.
Lavandera et al. ${ }^{15}$ implemented a program (3 sessions/week, 6 weeks) in school children $9.9 \pm 0.6$ years, and obtained an improvement of $2.7 \mathrm{~cm}$ in the $\mathrm{EG}$.

The study by Moreira et al. ${ }^{16}$ presented a great similarity with the present study. They applied a specific program (2 sessions/week, 6 weeks) and used the SRT by first measuring point 0. Moreira et al. ${ }^{16}$ observed an improvement of $3.4 \mathrm{~cm}$. and our study of $3.54 \mathrm{~cm}$.

When comparing our results with those of other investigators, we show greater improvements in hamstring flexibility compared to those reported by Valdivia et al. ${ }^{13}$ and Lavandera et al. ${ }^{15}$, even though Valdivia et al. ${ }^{13}$ applied longer intervention than what we used in this study. Nonetheless, these results are similar to Moreira et al. ${ }^{16}$, even though the tests used to measure flexibility were different. With regard to the study of Sainz de Baranda et al. ${ }^{12}$, these investigators showed greater improvements in flexibility than those in this study. We believe this may be due to the subjects' age and gender, as these two variables strongly influence lack of flexibility in these subjects. Different authors suggest the existence of a regression in the development of body flexibility; thus, with an increase in age there is a reduction in the elongation capacity of the muscles and, consequently, reduced joint mobility.

Just Sainz de Baranda et al. ${ }^{12}$ study discussed above, applies the test TT as our study. EG1 of Sainz de Baranda's studiy obtained an improvement of $7 \mathrm{~cm}$; EG2 and EG3, $11 \mathrm{~cm}$. Our study just shows an improvement of $3.54 \mathrm{~cm}$, in addition the bases scores differ between our work and commented. Discrepancies regarding home scores, flexibility and its progression may be due to the age of the subjects, or the duration of the intervention program (32 weeks).

To our knowledge, only three studies analyze the degree of muscular shortness. Sainz de Baranda et al. ${ }^{12}$ Rodríguez et al. ${ }^{17}$ and Peña ${ }^{18}$. These studies showed an improvement in flexibility of 32\%, 48\%, $26 \%{ }^{12} 5 \%, 4 \%{ }^{14}$, and $7 \%{ }^{18}$; whereas in our study we observed an increase of $15 \%$. The observed differences between the work of Sainz de Baranda et al. ${ }^{12}$ and ours, in terms of the percentages of improvement and evolution of EG might be due to different time duration of the program, and as discussed above, the existence of a regression in the development of body flexibility regarding age. Furthermore, although the studies by Rodriguez et al. ${ }^{17}$ and Peña ${ }^{18}$ utilized a longer duration compared to this study (32 weeks vs. 6 weeks), their programs are flexibility specific and in some cases the participants were younger than ours. Nonetheless, the reduction in hamstring shortness after their program is lower than ours.

Overall, both hamstring flexibility programs and the Pilates specific program have shown positive results in the elongation of the hamstring muscles among adolescents. It should be noted that the type of program, the duration, the participant's age and sex can influence the results, making them more or less effective than the Pilates program. Therefore, Pilates can be used to improve hamstring flexibility of school children, with the advantage that we can work the body as a whole with a variety of exercises that are not only focusing on the hamstring area.

Stretching exercises are an important tool to influence the decreased ability of muscle extensibility age. Moreover, the Pilates method was shown to be effective for both middle-aged and adolescent. So it becomes a method that can help preserve the health of the back.

Although our sample is larger than other similar studies, study's limitation could be this one. In further research it would be necessary an assessment the back pain in order to assessment the effect of the Pilates Method has on back pain in adolescents. 
Therefore, additional studies should consider the need to further evaluate the effect of the PM on flexibility, the importance of measuring pain and risk of injury, and compare it to other highquality studies.

\section{CONCLUSIONS}

After 6 weeks of exercise with the PM, GE teenagers significantly improved their hamstring flexibility suggesting that the Pilates method might be more effective in improving flexibility than a general physical education program. This study supports the notion that a Pilates method program might be a good method to use in schools to improve the flexibility in teenagers.

All authors have declared there is not any potential conflict of interests concerning this article.

\section{REFERENCES}

1. Micheo W, Baerga L, Miranda G. Basic principles regarding strength, flexibility, and stability exercises. PM R. 2012;4(11):805-11.

2. Walker B. Anatomía de las lesiones deportivas. Barcelona: Paidotribo; 2010.

3. van Middelkoop M, Rubinstein SM, Kuijpers T, Verhagen AP, Ostelo R, Koes BW, et al. A systematic review on the effectiveness of physical and rehabilitation interventions for chronic non-specific low back pain. Eur Spine J. 2011;20(1):19-39.

4. Luque-Suárez A, Fuente-Hervías MT, Barón-López FJ, Labajos-Manzanares MT. Relación entre el test de elevación de la pierna recta y el test del ángulo poplíteo en la medición de la extensibilidad isquiosural. Fisioterapia. 2010;32(6):256-63.

5. Ferrer $\mathrm{V}$. Repercusiones de la cortedad isquiosural sobre la pelvis y el raquis lumbar [thesis]. Murcia: Universidad de Murcia; 1998.

6. Houghton KM. Review for the generalist: evaluation of low back pain in children and adolescents. Pediatr Rheumatol Online J. 2010;8:28

7. Calvo-Muñoz I, Gómez-Conesa A, Sánchez-Meca J. Prevalence of low back pain during childhood and adolescence: a systematic review. Rev Esp Salud Publica. 2012;86(4):331-56.

8. González JL, Martínez J, Mora J, Salto G, Álvarez E. El dolor de espalda y los desequilibrios musculares. Rev Int Med Cienc Act Fís Deporte. 2004;4(13):18-34.

9. Hemmatinezhad MA, Afsharnezhad T, Nateghi N, Damirchi A. The relationship between limb length with classical and modified back saver sit and-reach tests in student boys. Int J Fitness. 2009;5(1):69-78.

10. Nelson RT, Bandy WD. Eccentric training and static stretching improve hamstring flexibility of high school males. J Athl Train. 2004;39(3):254-258

11. Reid DA, McNair PJ. Passive force, angle, and stiffness changes after stretching of hamstring muscles. Med Sci Sports Exerc. 2004;36(11):1944-8.

12. Sainz de Baranda P, Rodríguez PL, Santonja F, Andujar P. La columna vertebral del escolar. Sevilla: Wanceulen; 2006

13. Valdivia R, Calero F, Orlando L. Programas de ejercicios físicos de estiramientos para la mejora del acortamiento isquiosural. EFDesportes. 2011;15(154):1-16.

14. Coledam DHC, Arruda GA, Ramos de Oliveira A. Chronic effect of static stretching performed during warm-up on flexibility in children. Rev Bras Cineantropom Desempenho Hum. 2012;14(3):296-304.

15. Lavandera A, Abadia O, Azael J. Influencia de un trabajo de flexibilidad en las clases de educación física en primaria. EFDdeportes. 2006;11(100):1-8.

16. Moreira RF, Akagi FH, Wun PY, Moriguchi CS, Sato TO. Effects of a school based exercise program on children's resistance and flexibility. Work. 2012;41(Suppl1):922-8.

17. Rodríguez PL, Santonja F, Canteras M, Delgado M, Fernández J, Balsalobre, J. Mejora de la extensibilidad isquiosural tras un programa escolar de estiramientos. Selección. 1999;8(4):15-22.

18. Peña, W.A. Educación Física y Salud:Programa para la mejora del raquis en el plano sagital y la extensibilidad Isquiosural en Secundaria y Bachillerato. [thesis]. Murcia: Universidad de Murcia; 2010

19. González-Gálvez N, Sainz de Baranda P. El método pilares: aplicación práctica e investigación. Sevilla: Wanceulen; 2011

20. García-Pastor T, Aznar-Lain S. Práctica del MP: cambios en composición corporal y flexibilidad en adultos sanos. Apunts Med Esport. 2011;46(169):17-22

21. Kloubec JA. Pilates for improvement of muscle endurance, flexibility, balance, and posture. J Strength Cond Res. 2010;24(3):661-7.

22. Santana FJ, Fernández E, Merino R. Efectos del método Pilares sobre las capaciddes de fuerza, flexibilidad, agilidad y equilibrio en ciclismo profesional de mountain bike. J Sport Health Res. 2010;2(1):41-54

23. Hui SS, Yuen PY. Validity of the modified back-saver sit-and-reach test: a comparison with other protocols. Med Sci Sports Exerc. 2000;32(9):1655-9.

24. Ayala F, Sainz de Baranda P, De Ste Croix M, Santonja F. Fiabilidad y validez de las pruebas sit-and-reach: revisión sistemática. Rev Andal Med Deporte. 2012;5(2):53-62.

25. Sainz de Baranda P, Ayala F, Cejudo A, Santonja F. Descripción y análisis de la utilidad de las pruebas sit-and-reach para la estimación de la flexibilidad de la musculatura isquiosural. Rev Esp Educ Físic Deportes. 2012;396:119-33

26. Santonja F, Ferrer V, Martínez I. Exploracion clinica del sindrome de isquiosurales cortos. Selección. 1995;4(2):81-91.

27. González N, Carrasco M, Marcos PJ. El Método Pilates: una propuesta didáctica para $3^{\circ}$ de educación secundaria obligatoria. EmásF Rev Digital Educ Física. 2013;4(24):8-20. Disponível em: http://dialnet. unirioja.es/servlet/articulo?codigo $=4692440$ 